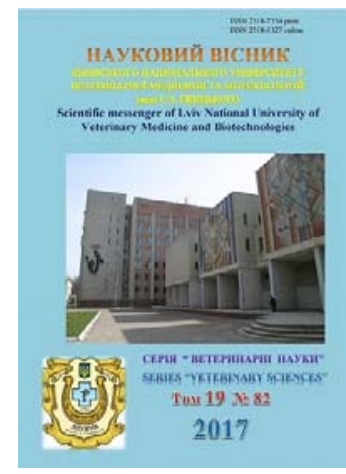

Науковий вісник Львівського національного університету ветеринарної медицини та біотехнологій імені С.З. Гжицького

Scientific Messenger of Lviv National University of Veterinary Medicine and Biotechnologies

doi:10.15421/nvlvet8214

ISSN 2518-7554 print

ISSN 2518-1327 online

$\underline{\text { http://nvlvet.com.ua/ }}$

УДК 639.3.09:579.62:597

\title{
Антимікробна активність нового хіміотерапевтичного препарату на основі флюмеквіну щодо Aeromonas Hydrophila
}

\author{
Х.Я. Солопова ${ }^{1}$, О.І. Віщур ${ }^{1}$, Т.І. Стецько ${ }^{2}$, Г.П. Угрин ${ }^{2}$, О.І. Хом'як ${ }^{2}$ \\ khrystyna.solopova@gmail.com \\ ${ }^{1}$ Інститут біології тварин НААН, \\ вул. В.Стуса, 38, Львів, 79000, Україна; \\ ${ }^{2}$ Державний науково-дослідний контрольний інститут ветеринарних препаратів та кормових добавок, \\ вул. Донецька, 11, м. Львів, 79019, Україна
}

\begin{abstract}
У статті подані дані дослідження антимікробної активності вітчизняного хіміотерапевтичного препарату на основі діючої речовини - флюмеквіну.

Визначали чутливість мікрофлори біоматеріалу до антибіотиків та мінімальні інгібуючі концентрачії флюмеквіну діючої речовини препарату «Флюмек».

Для дослідження було відібрано 5 риб - коропів, уражених аеромонозом. Діагноз на аеромоноз був поставлений на основі епізоотологічних даних, клінічних ознак захворювання, патолого-анатомічних змін та результатів бактеріологічного дослідження. Рибу розтинали і робили посіви із уражених ділянок шкіри, печінки та нирок. Посіви проводили на м'ясопептонний бульйон (МПБ) і м'ясо-пептонний агар (МПА). Посіви інкубували в термостаті за температури $26{ }^{\circ} \mathrm{C}$ упродовж 48 год. Чутливість мікрофлори біоматеріалу до антибіотиків визначали методом дифузї в агар з використанням стандартних дисків з антибіотиками та середовища Мюллера-Хінтона. Для виділення та ідентифікачії бактерії Aeromonas hydrophila робили первинний посів патологічного матеріалу на МПА, який інкубували в термостаті за температури $26{ }^{\circ} \mathrm{C}$ упродовж 24 год. Наступним етапом було виділення чистих культур мікроорганізмів та виготовлення мазків, які фарбували за Грамом у модифікаиї Бьорка. Методом серійних розведень у рідкому поживному середовищі визначали мінімальні інгібуючі концентрачії (МIК) флюмеквіну в препараті «Флюмек» для ізолятів Aeromonas hydrophila.

Результати тесту на чутливість мікрофлори біоматеріалу від хворих на аеромоноз риб показали високу чутливість мікроорганізмів до флюмеквіну, тетрачикліну, флуорфеніколу і триметоприму, помірну чутливість до неоміцину і резистентність - до амоксициліну, тилозину, лінкоміцину і колістину. Діаметр зони затримки росту культури навколо дисків $з$ флюмеквіном становив у культурах, висіяних з шкірних покривів - 23,2 мм, з нирок-30,0 мм, з печінки - 30,4 мм.

Згідно з отриманими значенями мінімальних інгібуючих концентрацій флюмеквіну усі досліджувані ізоляти Аетотопам hydrophila були чутливими до препарату «Флюмек» та становили 1,0-2,0 мкг/мл

Отже, результати проведених досліджень свідчать про те, щзо фторхінолоновий антибіотик флюмеквін володіє високою антимікробною активністю проти бактерії Aeromonas hydrophila, збудника аеромонозу коропових риб.

Ключові слова: антибактеріальний препарат, «Флюмек», флюмеквін, фторхінолон, короп, антимікробна активність, мінімальна інгібуюча кониентрачія, мікрофлора риб, аеромоноз, Aeromonas Hydrophila.
\end{abstract}

\section{Антимикробная активность нового химиотерапевтического препарата на основе флюмеквина по отношению к Aeromonas Hydrophila}

\author{
khrystyna.solopova@gmail.com \\ ${ }^{1}$ Институт биологии животных НААН, \\ ул. В. Стуса, 38, Львов, 79000, Украина;
}

Х.Я. Солопова ${ }^{1}$, О.И. Вищур ${ }^{1}$, Т.И. Стецько ${ }^{2}$, Г.П. Угрин ${ }^{2}$, А.И. Хомьяк ${ }^{2}$

Citation:

Solopova, H., Vishchur, O., Stetsko, T.I., Ugrin, G.P., Hom'jak, O.I. (2017). Antimicrobic activity of a new chemotherapeutic drug on the basis of flumequine at relatively to aeromonas hydrophila. Scientific Messenger LNUVMB, 19(82), 66-70. 
${ }^{2}$ Государственный научно-исследовательский контрольный институт ветеринарних препаратов и кормовых добавок, ул. Донеикая, 11, г. Львов, 79019, Украина

В статье представлены данные исследования антимикробной активности отечественного химиотерапевтического препарата на основе действующего вещества - флюмеквина.

Определяли чувствительность микрофлоры биоматериала к антибиотикам и минимальные ингибируюшие концентраиии флюмеквина - действующего вещества препарата «Флюмек».

Для исследования было отобрано 5 рыб - карпов, пораженных Аэромонозом. Диагноз на аэромоноз был поставлен на основе эпизоотологических данных, клинических признаков заболевания, патологоанатомических изменений и результатов бактериологического исследования. Рыбу вскрывали и делали посевы с пораженных участков кожи, печени и почек. Посевы проводили на мясопептонном бульоне (МПБ) и мясопептонном агаре (МПА). После чего посевы инкубировали в термостате при температуре $26{ }^{\circ} \mathrm{C}$ в течение 48 ч. Чувствительность микрофлоры биоматериала к антибиотикам устанавливали методом диффузии в агаре с использованием стандартных дисков с антибиотиками и среды Мюллера-Хинтона. Для выделения и идентификаџии бактерии Aeromonas hydrophila делали первичный посев патологического материала на МПА, который инкубировали в термостате при температуре $26{ }^{\circ} \mathrm{C}$ в течение 24 ч. Следуюшим этапом было выделение чистых культур микроорганизмов и изготовление мазков, которые красили по Грамму в модификачии Берка. Методом серийных разведений в жидкой питательной среде определяли минимальные ингибирующие концентрации (МИК) флюмеквину в препарате «Флюмек» для изолятов Aeromonas hydrophila.

Результаты теста на чувствительность микрофлоры биоматериала от больных аэромонозом рыб показали высокую чувствительность микроорганизмов к флюмеквину, тетрациклину, флуорфениколу и триметоприму, умеренную чувствительность к неомицину и резистентность - к амоксициллину, тилозину, линкомицину и колистину. Диаметр зоны задержки роста культуры вокруг дисков с флюмеквином составил в культурах, высеянных с кожных покровов - 23,2 мм, почек30,0 мм, печени - 30,4 мм.

Согласно полученных значений МИК флюмеквина все исследуемые изоляты Aeromonas hydrophila были чувствительными к препарату «Флюмек» и составляли 1,0-2,0 мкг/мл

Таким образом, результаты проведенных исследований свидетельствуют о том, что фторхинолонов антибиотик флюмеквин обладает высокой антимикробной активностью против бактерии Aeromonas hydrophila, возбудителя аэромоноза карповых рыб.

Ключевые слова: антибактериальный препарат, «Флюмек», флюмеквин, фторхинолон, карп, антимикробная активность, минимальная ингибирующая конщентрация, микрофлора рыб, аэромоноз, Aeromonas Hydrophila.

\title{
Antimicrobic activity of a new chemotherapeutic drug on the basis of flumequine at relatively to aeromonas hydrophila
}

\author{
H. Solopova ${ }^{1}$, O. Vishchur ${ }^{1}$, T.I. Stetsko ${ }^{2}$, G.P. Ugrin², O.I. Hom'jak ${ }^{2}$ \\ khrystyna.solopova@gmail.com \\ ${ }^{1}$ Institute of animal biology of NAAS, \\ Vasyl Stus Str., 38, Lviv, 79000, Ukraine; \\ ${ }^{2}$ State Scientific-Research Control Institute of Veterinary Medicinal Products and Feed Additives, \\ Donetska Str., 11, Lviv, 79019, Ukraine
}

In the article presented results of study of the antimicrobial activity of the chemotherapeutic drug on the basis of the active substance-flumequine.

The sensitivity of the microflora of the biomaterial to antibiotics was determined and the minimum inhibitory concentrations of flumequin, the active substance of the drug «Flyumek», were determined.

For the study were selected 5 fish - carps affected by aeromonosis. The diagnosis for aeromonosis was based on epizootological data, clinical signs of the disease, pathological and anatomical changes and the results of bacteriological research. The fish were slaughtered and crops were made from the affected parts of the skin, liver and kidneys. Sowing was carried out on meat-peptone broth (MPB) and meat-peptone agar (MPA). The seeds were incubated in a thermostat at a temperature of $26{ }^{\circ} \mathrm{C}$ for 48 hours. The sensitivity of the microflora of the biomaterial to antibiotics was determined by agar diffusion using standard antibiotic disks and the Müller-Hinton medium. In order to isolate and identify the Aeromonas hydrophila bacterium, the primary culture of the pathological material was performed on the MPA, which was incubated in the thermostat at $26^{\circ} \mathrm{C}$ for 24 hours. The next step was to isolate pure cultures of microorganisms and make smears that were stained with Gram in the Björk modification. The method of serial dilutions in a liquid nutrient medium was determined by the minimum inhibitory concentrations (MICs) of flumequine in the preparation of «Flyumek» for Aeromonas hydrophila isolates.

The results of the test for the sensitivity of the microflora of the biomaterial from the patient to the aeromonosis of the fish showed high sensitivity of the microorganisms to flumequin, tetracycline, fluorophenicol and trimethoprim, moderate neomycin sensitivity and resistance to amoxicilline, tylosine, lincomycine and colistine. The diameter of the growth retardation zone around the disks with flumequin was -23,2 mm in the crop sown from the skin, from the kidneys - 30,0 mm, from the liver-30,4 mm.

According to the obtained values of the minimum inhibitory concentrations of flumequine, all investigated isolates of Aeromonas hydrophila were sensitive to the drug «Flyumek» and amounted to $1.0-2.0 \mu \mathrm{g} \mathrm{ml}$.

The results of the conducted studies indicate that fluoroquinolone antibiotic flumequin has a high antimicrobial activity against the bacterium Aeromonas hydrophila, an aeromonosis agent of carp fish.

Key words: antibiotic, "Flyumek», flumequin, fluoroquinolone, carp, antimicrobial activity, minimal inhibitory concentration, fish microflora, aeromonosis, Aeromonas Hydrophila. 


\section{Вступ}

Хвороби риб наносять значні економічні збитки світовій аквакультурі. Вивчення закономірностей їх виникнення та поширення, розробка заходів запобігання є важливою проблемою сучасного рибництва, оскільки від іiі вирішення залежить ефективність відтворення та вирощування рибних об'єктів, збереження рибної продукції (Vovk and Bozhik, 2014).

Аеромоноз (краснуха) коропових риб належить до одного 3 найпоширеніших захворювань ставкових риб, яке завдає значної шкоди рибництву. Відхід риби внаслідок цього захворювання становить 10-90\% (Davydov et al., 2009). Збудником захворювання найчастіше є бактерія Aeromonas hydrophila яка відноситься до роду Aeromonas, сімейства Vibrionaceae (Roberts, 2012).

У рибництві для лікування та профілактики інфекційних захворювань бактеріальної етіології широко використовуються антибіотики. Незважаючи на недоліки використання антибіотиків у рибництві, таких як поява антибіотикорезистентних штамів бактерій, відносно тривалий термін каренції (21-28 днів), ця група хіміотерапевтичних препаратів залишається однією з найбільш ефективних при лікування бактеріальних інфекцій у риб, особливо при ранніх проявах захворювання (Davydov et al., 2009).

На сьогоднішні антибіотики фторхінолонової групи займають чільне місце у ветеринарній антибіотикотерапії. Фторхінолони - це синтетичні хіміотерапевтичні засоби широкого спектра дії. Для фторхінолонів характерний унікальний серед антимікробних препаратів механізм дії - інгібування ферменту бактеріальної клітини ДНК-гідрази і топоізомераза IV, що приводить до порушення поділу бактеріальних клітин. Дуже важливим $є$ той факт, що резистентність до фторхінолонів розвивається дуже повільно. Більшість фторхінолонів діє на мікроорганізми, резистентні до бета-лактамних антибіотиків, тетрациклінів, аміноглікозидів, антагоністів фолієвої кислоти та до інших антибактеріальних речовин (Gunchak and Stetsko, 2012).

Мета досліджень полягала у визначенні чутливості польових штамів Aeromonas hydrophila, збудника аеромонозу коропів, до нового вітчизняного антибактеріального препарату «Флюмек» (порошок для перорального застосування), діючою речовиною якого є флюмеквін.

\section{Матеріали і методи досліджень}

Дослідження проводили на базі Львівської дослідної станції Інституту рибного господарства НААН (смт Великий Любінь) та Державного науководослідного контрольного інституту ветеринарних препаратів та кормових добавок (м. Львів). Діагноз на аеромоноз коропів був поставлений на основі епізоотологічних даних, клінічних ознак захворювання, патолого-анатомічних змін та результатів бактеріологічного дослідження. Для дослідження брали 5 живих риб. Рибу розтинали і робили посіви із уражених ді- лянок шкіри, печінки та нирок. Посіви проводили на м'ясо-пептонний бульйон i м'ясо-пептонний агар. Посіви інкубували в термостаті за температури $26^{\circ} \mathrm{C}$ упродовж 48 год.

Чутливість мікрофлори біоматеріалу до антибіотиків встановлювали методом дифузії в агар з використанням стандартних дисків 3 антибіотиками та середовища Мюллера-Хінтона, виробництва HiMedia Laboratories Pvt Ltd. Для визначення чутливості мікроорганізмів до флюмеквіну готували стерильні паперові диски, які просочували розчином препарату «Флюмек» так, щоб диск містив 50 мкг флюмеквіну. Результати тесту на чутливість інтерпретували згідно 3 Performance Standards for Antimicrobial Disk and Dilution Susceptibility Tests for Bacteria Isolated from Animals.

Для виділення та ідентифікації бактерії Aeromonas hydrophila робили первинний посів патологічного матеріалу на поживне середовище - м'ясо-пептонний агар, яке інкубували в термостаті за температури $26^{\circ} \mathrm{C}$ впродовж 24 год. Наступним етапом було виділення чистих культур мікроорганізмів та виготовлення мазків, які фарбували за Грамом у модифікації Бьорка.

Методом серійних розведень у рідкому поживному середовищі визначали мінімальні інгібуючі концентрації (МІК) флюмеквіну в препараті «Флюмек» для ізолятів Aeromonas hydrophila. Для цього готували розведення препарату з такими концентраціями флюмеквіну: $250 ; 125 ; 62,5 ; 31,5 ; 16,0 ; 8,0 ; 4,0 ; 2,0 ; 1,0$; 0,$5 ; 0,25$ мкг/мл. Отримані значення МІК флюмеквіну інтерпретували таким чином: MIК $\leq 2$ мкг/мл - штам чутливий; МІК = 4 мкг/мл - штам помірно чутливий; МІК $\geq 8$ мкг/мл - штам резистентний.

\section{Результати та їх обговорення}

Результати тесту на чутливість біоматеріалу до антибіотиків, виконаного диско-дифузійним методом, наведені у таблиці 1.

Результати тесту на чутливість мікрофлори біоматеріалу від хворих на аеромоноз риб показали високу чутливість мікроорганізмів до флюмеквіну, тетрациклінів, флуорфеніколу і триметоприму, помірну чутливість до неоміцину і резистентність - до амоксициліну, тилозину, лінкоміцину і колістину.

Посів 3 внутрішніх органів у поживний бульйон (МПБ) дав рівномірне помутніння середовища та утворення плівки. Висів бактеріальної суспензії на МПА дав ріст на середовищі круглих, щільних, блискучих з рівними краями, голубуватого відтінку колоній. У фарбованих за Грамом мазках, приготовлених 3 поверхневих уражених частин шкіри, крові серця, внутрішньочеревної рідини, у полі зору були виявлені палички червоного кольору. Такі морфологічні та культуральні властивості характерні для умовнопатогенної бактерії Aeromonas hydrophila.

Результати визначення рівня бактеріостатичної активності препарату «Флюмек» стосовно до ізолятів Aeromonas hydrophila наведені у таблиці 2. 
Таблицяя 1

Чутливість мікрофлори біоматеріалу хворих на аеромоноз коропів до антибіотиків, $\mathbf{n}=\mathbf{5}(\mathbf{M} \pm \mathbf{m})$

\begin{tabular}{|c|c|c|c|c|c|c|c|}
\hline \multirow[b]{2}{*}{ Антибіотик } & \multirow{2}{*}{$\begin{array}{c}\text { Вміст } \\
\text { в диску, } \\
\text { мкг }\end{array}$} & \multicolumn{2}{|c|}{ Шкіра } & \multicolumn{2}{|c|}{ Нирки } & \multicolumn{2}{|c|}{ Печінка } \\
\hline & & $\begin{array}{c}\text { діаметр зони } \\
\text { інгібування, } \\
\text { мм }\end{array}$ & $\begin{array}{c}\text { рівень } \\
\text { чутливості }\end{array}$ & $\begin{array}{c}\text { діаметр зони } \\
\text { інгібування, мм }\end{array}$ & $\begin{array}{c}\text { рівень } \\
\text { чутливості }\end{array}$ & $\begin{array}{c}\text { діаметр зони } \\
\text { інгібування, мм }\end{array}$ & $\begin{array}{c}\text { рівень } \\
\text { чутливості }\end{array}$ \\
\hline Окситетрациклін & 30 мкг & $19,4 \pm 1,5$ & пЧ & $25,6 \pm 1,3$ & Ч & $27,8 \pm 1,2$ & Ч \\
\hline Амоксицилін & 10 мкг & - & $\mathrm{P}$ & - & $\mathrm{P}$ & - & $\mathrm{P}$ \\
\hline Флуорфенікол & 30 мкг & $22,2 \pm 1,2$ & Ч & $22,2 \pm 1,2$ & Ч & $21,2 \pm 2,0$ & Ч \\
\hline Хлортетрациклін & 30 мкг & $27,2 \pm 1,1$ & Ч & $29 \pm 1,8$ & Ч & $30 \pm 1,3$ & Ч \\
\hline Неоміцин & 10 мкг & $14 \pm 1,2$ & пЧ & $15,8 \pm 1,4$ & пЧ & $16,8 \pm 0,8$ & пЧ \\
\hline Тилозин & 15 мкг & - & $\mathrm{P}$ & - & $P$ & - & $\mathrm{P}$ \\
\hline Лінкоміцин & 10 мкг & - & $\mathrm{P}$ & - & $\mathrm{P}$ & - & $\mathrm{P}$ \\
\hline Колістин & 10 мкг & - & $\mathrm{P}$ & - & $\mathrm{P}$ & - & $\mathrm{P}$ \\
\hline Триметоприм & 5 мкг & $23,8 \pm 1,4$ & Ч & $22 \pm 1,6$ & Ч & $23,2 \pm 1,8$ & Ч \\
\hline $\begin{array}{l}\text { Флюмек } \\
\text { (флюмеквін) }\end{array}$ & 50 мкг & $23,2 \pm 1,5$ & $\mathrm{P}$ & $30 \pm 1,6$ & Ч & $30,4 \pm 1,1$ & Ч \\
\hline
\end{tabular}

Примітки: 1) «Р» - мікрофлора резистентна; «пЧ» - мікрофлора помірно чутлива; «Ч» - мікрофлора чутлива; 2) для флюмеквіну: $\geq 20$ мм - мікрофлора чутлива; 19-17 мм - мікрофлора помірно чутлива; $\leq 16$ мм - мікрофлора чутлива.

Мінімальні інгібуючі концентрації флюмеквіну для ізолятів Aeromonas hydrophila $(\mathrm{n}=5)$

\begin{tabular}{|c|c|c|c|c|c|}
\hline \multirow{2}{*}{ Розведення, мкг/мл } & \multicolumn{5}{|c|}{ Ізоляти } \\
\cline { 2 - 6 } & 1 & 2 & 3 & 4 & 5 \\
\hline 250 & - & - & - & - & - \\
\hline 125 & - & - & - & - & - \\
\hline 62,5 & - & - & - & - & - \\
\hline 31,5 & - & - & - & - & - \\
\hline 16,0 & - & - & - & - & - \\
\hline 8,0 & - & - & - & - & - \\
\hline 4,0 & - & - & + & - & - \\
\hline 2,0 & - & + & + & & + \\
\hline 1,0 & + & + & 2,0 & & + \\
\hline 0,5 & 1,0 & 2,0 & & & - \\
\hline
\end{tabular}

Примітка: «-» - ріст відсутній (бульйон прозорий); «+» - ріст присутній (помутніння бульйону)

Згідно з отриманими значеннями МІК флюмеквіну усі досліджувані ізоляти Aeromonas hydrophila були чутливими до препарату «Флюмек».

Отримані результати дослідження антимікробної чутливості польових штамів Aeromonas hydrophila, виділених від хворої на аеромоноз риби сімейства коропових, показали, що зберігається високий рівень чутливості аеромонад до антибіотиків фторхінолонового ряду, у тому числі до флюмеквіну, діючої речовини антибактеріального препарату для застосування у ветеринарній медицині - «Флюмек».

\section{Висновки}

1. Фторхінолоновий антибіотик флюмеквін володіє високою антимікробною активністю проти бактеpiї Aeromonas hydrophila, збудника аеромонозу коропових риб.

2. Новий антибактеріальний препарат «Флюмек» на основі флюмеквіну може слугувати ефективним хіміотерапевтичним засобом етіотропної терапії аеромонозу риб сімейства коропових.

Перспективи подальших досліджень. Доцільним є дослідження ефективності та безпечності препарату «Флюмек» за лікування аеромонозу коропів в умовах рибних господарств.

\section{Бібліографічні посилання}

Davydov, O.N., Abramov, A.V., Kurovskaja, L.Ja. (2009). Biologicheskie preparaty i himicheskie veshhestva v akvakul'ture. K.: Logos. 21-39 (in Russian).

Gunchak, V.M., Stetsko, T.I. (2012) Osoblyvosti antybiotykoterapiyi u suchasnij veterynarnij medycyni. Naukovyj visnyk Lvivskogo nacionalnogo universytetu veterynarnoyi medycyny ta biotexnologij im. Gzhyczkogo. T. 14, № 2(1), 73-84 (in Ukrainian). 
Hrytsynyak, I.I., Tyshnitska, N.Y. (2011). Diagnostika, likuvannja ta zahodi profilaktiki asocijovanoi formi krasnuhi koropa. Kyiv. 5-14 (in Ukrainian).

Vovk, N.I., Bozhik, V.J. (2014) Ihtiopatologija. K.: Agroosvita, 3-5 (in Ukrainian).

Papich, M.G. (2015). VET01S. Performance Standards for Antimicrobial Disk and Dilution Susceptibility
Tests for Bacteria Isolated from Animals, 3rd Edition. Clinical and Laboratory Standards Institute. 50-112.

Roberts, R.J. (2012). Fish Pathology, Fourth Edition. Blackwell Publishing Ltd. 342-343.

Received 25.09.2017 Received in revised form 27.10.2017 Accepted 3.11.2017 